\title{
Luminescent Properties of Electrochemically Etched Gallium Arsenide
}

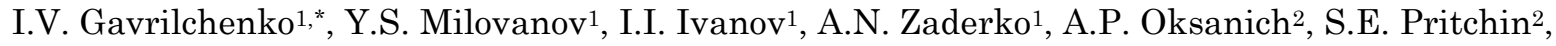 \\ M.G. Kogdas ${ }^{2}$, M.I. Fedorchenko ${ }^{3}$, S.N. Goysa ${ }^{3}$, V.A. Skryshevsky ${ }^{1}$ \\ ${ }_{1}^{1}$ Institute of High Technologies, Taras Shevchenko National University of Kyiv, 64, Volodymyrska St., \\ 01601 Kyiv, Ukraine \\ ${ }_{2}^{2}$ Kremenchuk Mykhailo Ostrohradskyi National University, 20, Pershotravneva St., 39600 Kremenchuk, Ukraine \\ ${ }^{3}$ Faculty of Radiophysics, Electronics and Computer Systems, Taras Shevchenko National University of Kyiv, \\ 64, Volodymyrska St., 01601 Kyiv, Ukraine
}

(Received 04 April 2021; revised manuscript received 09 August 2021; published online 20 August 2021)

\begin{abstract}
The paper presents the results of structural and photoluminescent (PL) studies of porous GaAs layers created by electrochemical etching of GaAs wafers. Structural and morphological properties of porous GaAs were analyzed by SEM and Auger spectroscopy. The analysis of SEM images shows the presence of meso- and macropores and nanocrystallites in the porous layer. Some samples have the pyramidal formations on the surface. Auger spectra of crystalline and porous GaAs show different stoichiometry of the samples. The photoluminescence of the formed material is characterized by the emission band in the region of 1.5-3.2 eV, and the dependence of the PL spectrum on the wavelength of exciting light is observed. As the wavelength of the exciting light increases, the maxima of the emission spectra shift to the region of lower energies. This behavior of the PL spectrum (shift of the PL maximum depending on the wavelength of excitation emission) is characteristic of heterogeneous in thickness electrochemically etched porous structures. The nature of the multiband PL spectrum of porous GaAs can be explained by the existence of hydrated oxides of arsenic and gallium on the surface of the samples and the formation of nanocrystallites in the porous layers of GaAs. The article presents an estimation of the possible sizes of nanocrystallites under the assumption that PL is created due to quantum-dimensional effects.
\end{abstract}

Keywords: Photoluminescence, Porous GaAs, Nanocrystallites, Auger spectroscopy.

DOI: $10.21272 /$ jnep.13(4).04011

PACS number: $78.55 .-\mathrm{m}$

\section{INTRODUCTION}

Modern technological development requires the search for new materials and structures for optoelectronics and sensor devices. After the discovery of visible luminescence in porous silicon (por-Si), significant progress has been made in the study of nanoscale structures. The role of quantum-dimensional effects in the formation of the photoluminescence (PL) spectrum was proved by the example of por-Si. Recently, it is possible to create similar porous nanostructured layers on binary and more complex materials that already have pronounced luminescent properties [1-3]. The simplest and most cost-effective approach to creating porous structures is the electrochemical etching of single-crystal or polycrystalline plates. In nanocrystalline structures, there is a quantum confinement effect, which changes the band structure of the material and leads to unique optical and luminescent properties [4]. Porous structures have already been created by electrochemical etching based on $\mathrm{A}^{3} \mathrm{~B}^{5}$ semiconductors, such as InP, GaAs and GaP. Among them, considerable attention is paid to porous GaAs, since it has luminescence in the visible region at higher energies than porous silicon [5]. The luminescent properties of porous GaAs make it possible to create sensors and light-emitting devices based on it [6]. By reducing optical losses, this material can increase the efficiency of photoelectric and photovoltaic devices, such as solar cells [7]. Porous GaAs can also be used as a substrate for growing other semiconductor materials [8-10], as well as chemical sensors [11]. Previous studies have shown that both the surface morphology and the porous structure of the layer play a crucial role [12, 13].

Today, there are works on the study of the PL spectra of porous GaAs, but they are quite contradictory. In particular, significant differences are observed in the position of the visible PL spectrum for different samples [1]. In addition, the nature of the visible PL of porous GaAs is unknown, as it can be caused by both quantum phenomena and the formation of new chemical compounds on the porous surface.

In this work, we studied the morphological, structural and photoluminescent properties of porous layers of GaAs.

\section{EXPERIMENT}

Samples of porous GaAs made by the method of anodic etching of $n$-type GaAs wafers (100) doped with Sn in $\mathrm{H}_{2} \mathrm{SO}_{4}-\mathrm{C}_{2} \mathrm{H}_{5} \mathrm{OH}$ solution were investigated. The etching modes and electrolyte composition are presented in Table 1. Before treatment, $n$-GaAs is usually purified with acetone and deionized water. During the experiment, it was found that the samples have a different morphological structure depending on the etching mode.

The surface of the selected samples was studied by the SEM method using scanning electron microscopes MIRA3 TESCAN and Magellan 400. In order to clarify the structural composition, Auger spectra were measured on the crystalline and porous surface of GaAs.

The PL spectra were measured on the setup using MS2004 monochromator and HAMAMATSU H7360-03

\footnotetext{
*ir.gavril11@gmail.com
} 
photoelectron multiplier. An ILGI-503 pulsed nitrogen laser with the following characteristics was used to excite luminescence: the radiation wavelength is $337 \mathrm{~nm}$, the average radiation power is about $3.7 \mathrm{~mW}$, the pulse repetition frequency is $100 \mathrm{~Hz}$, and the pulse duration is about $8 \mathrm{~ns}$. Additionally, semiconductor lasers with a wavelength of $405 \mathrm{~nm}$ (MDL-XS) and $523 \mathrm{~nm}$ were also applied for PL measurements.

Table 1 - Samples description

\begin{tabular}{|c|c|c|c|c|}
\hline \multirow[b]{2}{*}{$\begin{array}{c}\text { № of } \\
\text { sample }\end{array}$} & \multicolumn{2}{|c|}{ Etching mode } & \multirow[b]{2}{*}{ Etchant } & \multirow{2}{*}{$\begin{array}{l}\text { Concentration of } \\
\text { charge carriers of } \\
\text { the substrate, } \mathrm{cm}^{-3}\end{array}$} \\
\hline & \begin{tabular}{|c|} 
Current, \\
$\mathrm{mA} / \mathrm{cm}^{2}$
\end{tabular} & $\begin{array}{l}\text { Time, } \\
\text { min }\end{array}$ & & \\
\hline Series 1 & 10 & 10 & $\begin{array}{c}\mathrm{H}_{2} \mathrm{SO}_{4}: \mathrm{CH}_{5} \mathrm{OH} \\
=1: 1\end{array}$ & $4.8 \cdot 10^{16}$ \\
\hline Series 2 & 25 & 10 & $\begin{array}{c}\mathrm{H}_{2} \mathrm{SO}_{4}: \mathrm{CH}_{5} \mathrm{OH} \\
=1: 3\end{array}$ & $5.8 \cdot 10^{16}$ \\
\hline
\end{tabular}

\section{RESULTS AND DISCUSSION}

SEM images indicate the presence of a porous layer on the surface of GaAs with a thickness of about $20 \mu \mathrm{m}$, which consists of non-uniformly distributed meso- and macropores and nanocrystallites. Also, on the surface of series 1 samples, there are asperities of microrelief or island formations of a pyramidal shape with a height of $\sim 30 \mu \mathrm{m}$ (Fig. 1a, Fig. 2). Similar structures were observed in [14]. In contrast to series 1 samples, the SEM images of series 2 samples showed the absence of such pyramidal formations, which can be observed in Fig. $1 b$.

Auger spectra of the porous and crystalline parts of GaAs samples are presented in Fig. 3. It is seen that carbon and oxygen lines (KLL lines) appear on the GaAs surface after annealing of the sample at $140{ }^{\circ} \mathrm{C}$ (Fig. 3a). Moreover, on the porous part of the sample, the intensity of the carbon line is approximately three times greater than that on the crystalline part. This may mean that pores of GaAs are filled with compounds containing carbon (possibly residues of etchant), which at high annealing temperatures is desorbed from these pores. The presence of the oxygen line may indicate the presence of oxides on the surface of GaAs.

In the Auger spectrum, Ga and As lines (LMM) for the crystalline (1) and porous (2) parts of the GaAs sample are observed (Fig. $3 \mathrm{~b}$ ). The ratio of amplitudes of As and Ga Auger peaks for the porous surface was estimated as 0.85 , and for the crystalline surface as 0.68 , which may indicate different stoichiometry of GaAs on the porous and crystalline parts of the samples. This means that Ga is etched $20 \%$ more than As.

To study the optoelectric properties of the structures, the measurements of the PL spectra were performed. In order to detect structural features, PL was excited by a laser at several wavelengths (337, 405 and $532 \mathrm{~nm}$ ) (Fig. 4a). When excited by light with a wavelength of $337 \mathrm{~nm}$, PL in the short-wavelength region $(2.75-3.3 \mathrm{eV})$ is observed. It is seen that with an increase in the length of the exciting light to $405 \mathrm{~nm}$, the radiation spectra shift to the region of lower energies (1.7-3.0 eV). Such behavior of the PL spectra (shift of the PL maximum depending on the wavelength of excitation radiation) is characteristic of heterogeneous in thickness electrochemically etched porous structures. When the structure is illuminated by a laser with a wavelength of $532 \mathrm{~nm}$, there are a slight glow in the region of $2.0 \mathrm{eV}$ and an intense wide peak at $1.5 \mathrm{eV}$ in the IR region (for bulk GaAs, the maximum is approximately $1.42 \mathrm{eV})$.

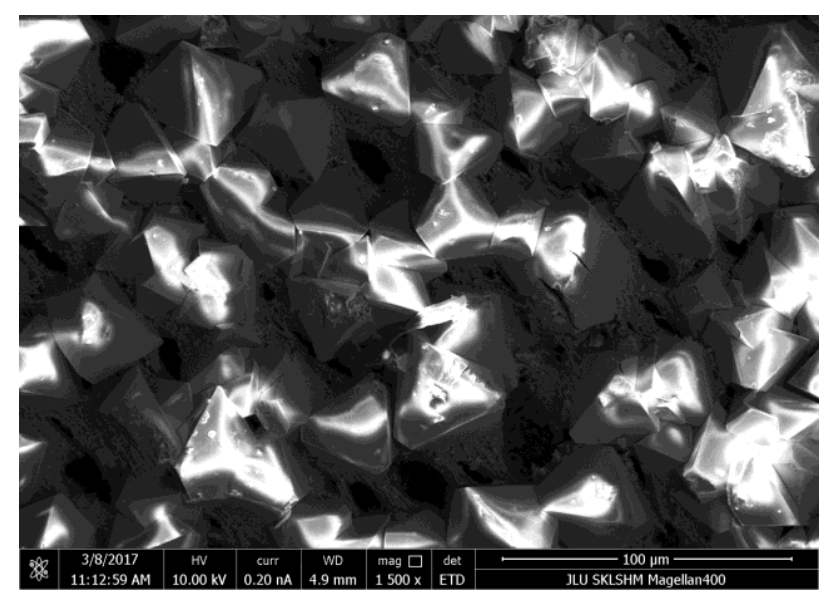

a

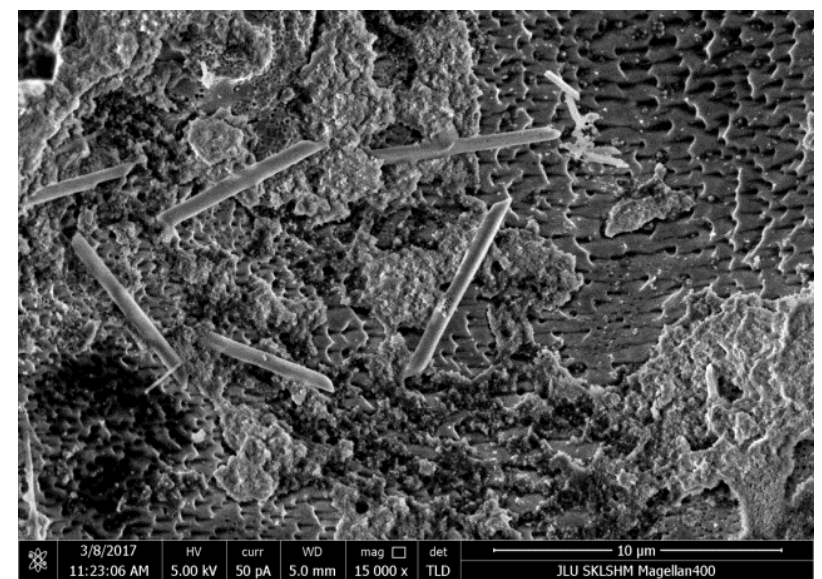

b

Fig. 1 - Surface of porous GaAs: a - samples of series 1 and b-samples of series 2

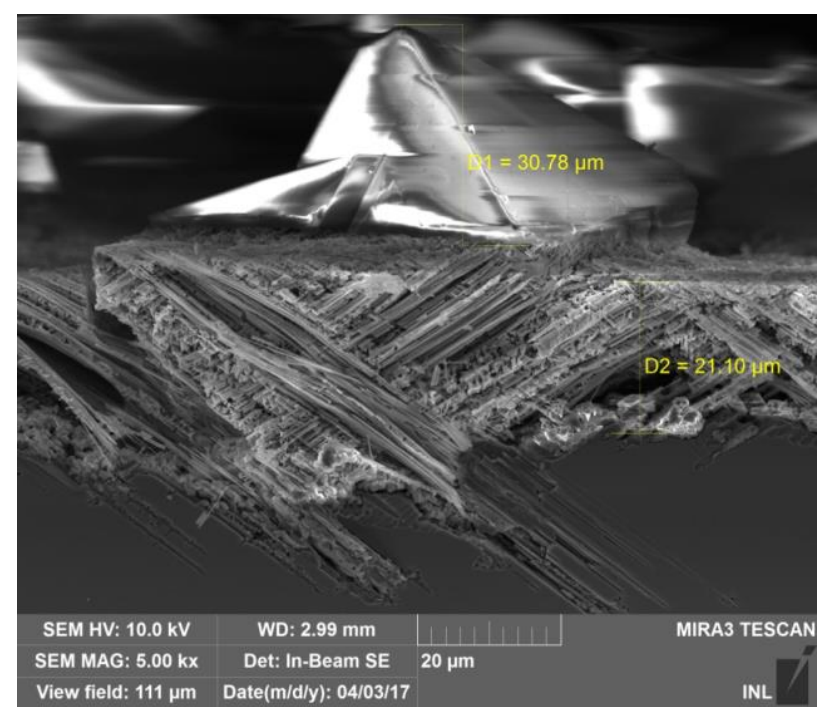

Fig. 2 - Chipping of the structure with a layer of porous GaAs (samples of series 1) 


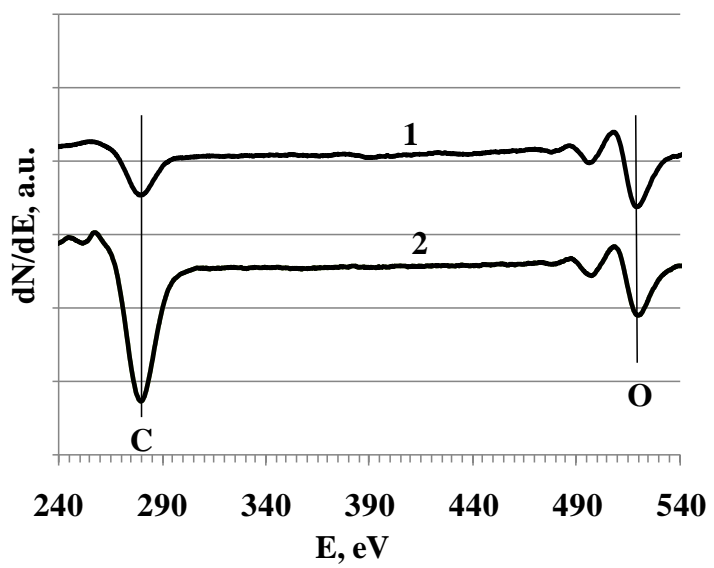

a

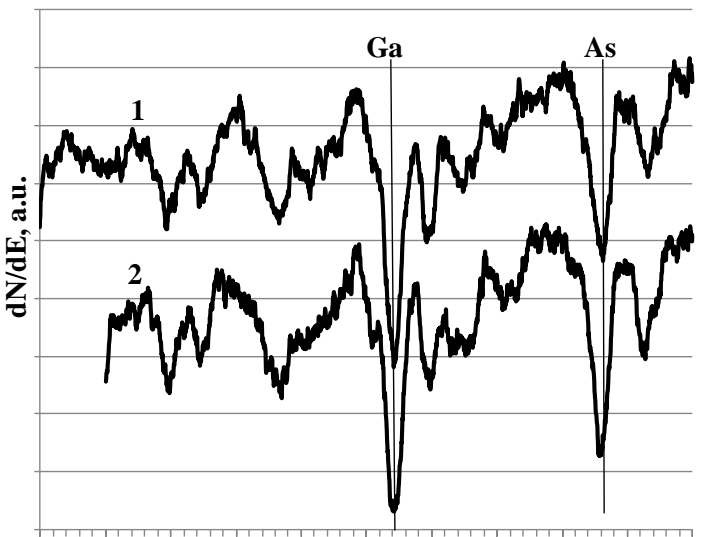

8008509009501000105011001150120012501300 E, eV

$\mathrm{b}$

Fig. 3 - Auger spectra of carbon and oxygen lines (a) and Ga and As lines (b) on the surface of GaAs after heating the sample to $140^{\circ} \mathrm{C}: 1$ - on the crystalline part of the sample; 2 - on the porous part of the sample

If we analyze the nature of the visible PL of porous GaAs, it should be noted that the etching of binary compounds is a more complex process than when obtaining, for example, porous silicon. This is due to different degrees of ionicity of the crystal lattices of binary semiconductors and different rates of transition into the solution of two different semiconductor components [1]. As a result, on the surface of the sample, there will be mainly a hydrated oxide of one of the elements. Which one - will be determined by the etchant composition and the etching mode. The formation of oxides is also possible at the stage of washing and drying of the samples. The physicochemical properties of such formations may differ from the properties of the original semiconductor. Thus, Fig. 4b shows the PL spectra of hydrated oxides of As and Ga for comparison [1]. After analyzing the nature of the spectra, we can draw the following conclusions. The spectrum of hydrated oxide $\mathrm{As}_{2} \mathrm{O}_{3} \cdot n \mathrm{H}_{2} \mathrm{O}$ is very similar to the spectrum of porous GaAs at excitation at $337 \mathrm{~nm}$, the maximum emission is in the same region. This means that PL in this case is primarily due to the presence of hydrated As oxides on the surface of the porous structure. This is consistent with our data from Auger spectra and with the work of other authors $[1,2]$. But, at the same time, differences in the spectrum, namely, in the half-width and the presence of a fine structure, may indicate the presence of other mechanisms of PL, such as emission from nanocrystallites.

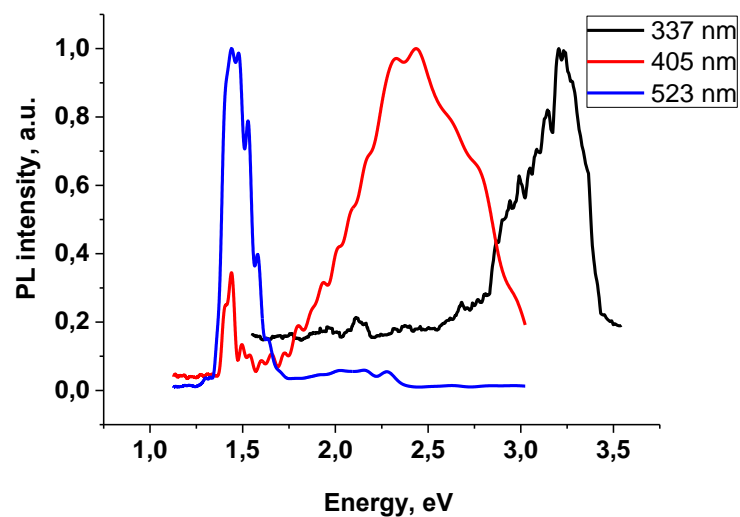

a

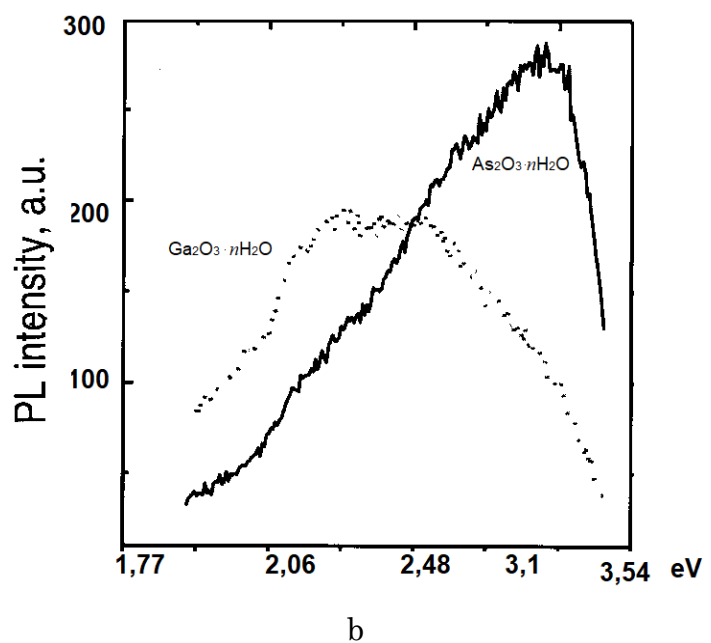

Fig. 4 - PL spectra of porous GaAS (a), visible PL spectra of hydrated oxides $\mathrm{As}_{2} \mathrm{O}_{3} \cdot n \mathrm{H}_{2} \mathrm{O}$ and $\mathrm{Ga}_{2} \mathrm{O}_{3} \cdot n \mathrm{H}_{2} \mathrm{O}$ (b) [1]

In favor of this explanation is the existence of a peak shift when the wavelength of the excitation radiation changes. Fig. 5 shows the PL spectra of GaAs samples excited with a laser with a wavelength of $337 \mathrm{~nm}$. The spectra are complex and can be divided into several bands of emission by decomposing them into Gaussians.

Let us try to estimate the size of nanocrystallites under the assumption that PL is created due to quantum-dimensional effects. In $[15,16]$, the correlation between PL emission maxima and nanocrystallite sizes is considered at the using of empirical model of Delerue, which was developed for silicon nanocrystallites. Therefore, in our case, we use the general formula for energy levels of nanocrystallites [16]:

$$
E=E_{g}+\frac{\pi^{2} h^{2}}{2 d^{2}}\left(\frac{1}{m_{e}^{*}}+\frac{1}{m_{h}^{*}}\right),
$$

where the diameter of nanocrystallites is

$$
d=\sqrt{\frac{\pi^{2} h^{2}\left(\frac{1}{m_{e}^{*}}+\frac{1}{m_{h}^{*}}\right)}{2 \Delta E} .}
$$


Here, $h$ is the reduced Planck constant, $\Delta E=E-E_{g}, E_{g}$ is the GaAs band gap, $m_{e}^{*}$ is the effective mass of the electron $\left(=0.067 m_{e}\right), m_{h}^{*}$ is the effective mass of the hole (light hole $=0.082 m_{e}$, heavy hole $=0.45 m_{e}$ ), $m_{e}$ is the electron mass [2].

The results of the analysis of the PL spectra and the calculations performed are given in Table 2 and Table 3. Here, FWHM is the Gaussian half-width, $D$ is the diameter of nanocrystallites (the diameters of nanocrystallites are determined by the formulas, the last column of Table 2 is determined from the graph). The table shows that the size of nanocrystallites is in the range of $4.8-11.4 \mathrm{~nm}$.

The obtained components of the emission spectra of the samples correlate with the previously studied emission spectra of gallium arsenide nanoparticles [17-19]. In particular, emission bands with energies of 2.88 and $2.75 \mathrm{eV}$ of crystallites with average sizes of 5.5-4.8 nm in colloidal solutions were observed in [17], and bands with energies of 2.25 and $2.34 \mathrm{eV}$ were observed in [18]. The sizes of crystallites calculated according to formula (3.1) are in the range of 5.2 to $6.5 \mathrm{~nm}$ (for crystallites that are responsible for emission at $2.92 \mathrm{eV}$ ) and of 5.5 to $6.9 \mathrm{~nm}$ (for crystallites that are responsible for emis-

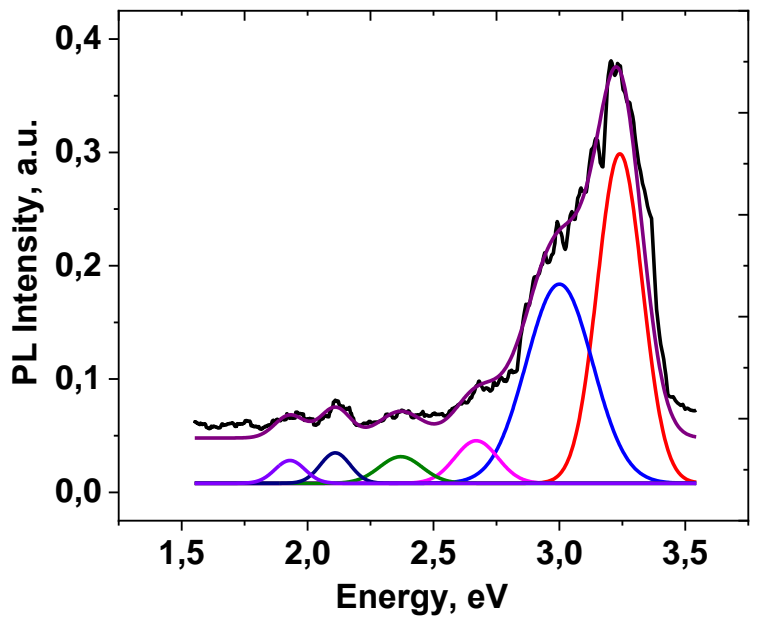

a

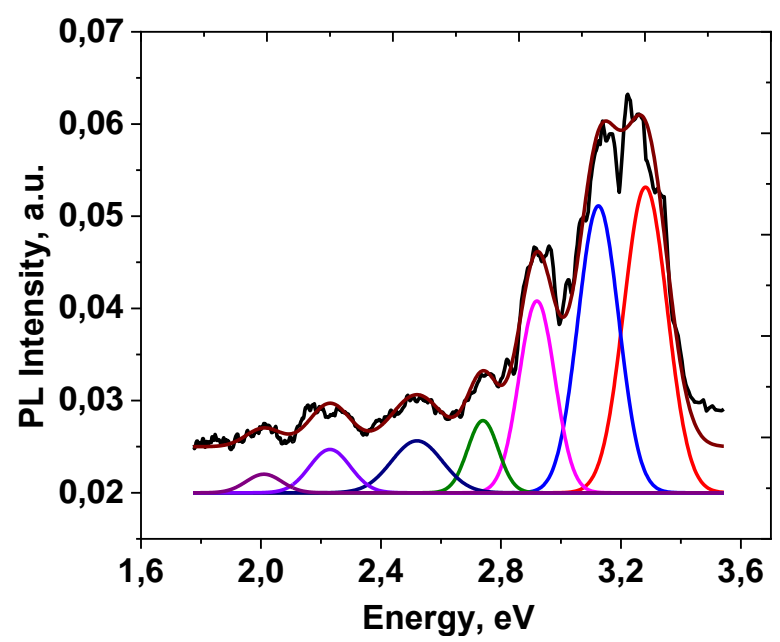

$\mathrm{b}$

Fig. 5 - Typical PL spectrum: a - for samples of series 1 and $\mathrm{b}$ - for samples of series 2

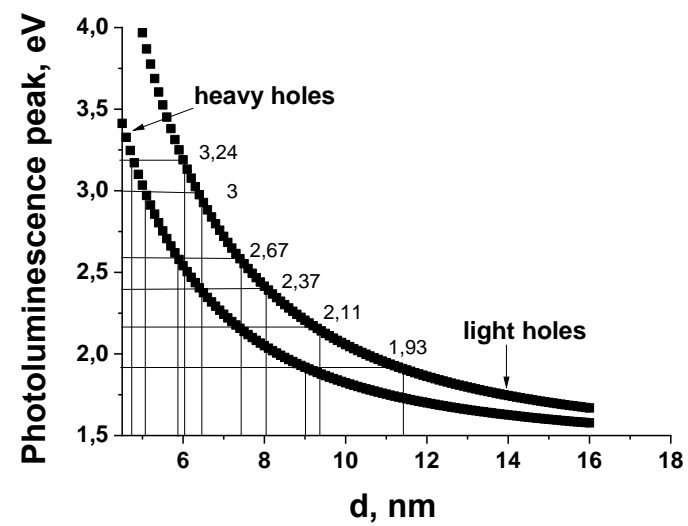

Fig. 6 - The energy of PL peaks depending on the diameter of nanocrystallites calculated according to formula (3.1)

Table 2 - GaAs series 1

\begin{tabular}{|c|c|c|c|}
\hline $\begin{array}{c}\text { Band gap, } \\
\mathrm{eV}\end{array}$ & $\begin{array}{c}\text { FWHM, } \\
\mathrm{eV}\end{array}$ & $\begin{array}{c}\text { Band gap } \\
\text { shift, eV }\end{array}$ & $\begin{array}{c}D, \mathrm{~nm} \\
\text { (from graph) }\end{array}$ \\
\hline 3.24 & 0.17 & 1.82 & $4.8-6$ \\
\hline 3 & 0.16 & 1.58 & $5.1-6,4$ \\
\hline 2.67 & 0.14 & 1.25 & $5.9-7,4$ \\
\hline 2.37 & 0.12 & 0.95 & $6.4-8$ \\
\hline 2.11 & 0.20 & 0.69 & $7.4-9.4$ \\
\hline 1.93 & 0.16 & 0.51 & $9.4-11.4$ \\
\hline
\end{tabular}

Table 3 - GaAs series 2

\begin{tabular}{|c|c|c|c|}
\hline $\begin{array}{c}\text { Band gap, } \\
\mathrm{eV}\end{array}$ & $\begin{array}{c}\text { FWHM, } \\
\mathrm{eV}\end{array}$ & $\begin{array}{c}\text { Band gap } \\
\text { shift, eV }\end{array}$ & $\begin{array}{c}D, \mathrm{~nm} \\
\text { (from graph) }\end{array}$ \\
\hline 3.28 & 0.17 & 1.8 & $4.7-5.9$ \\
\hline 3.13 & 0.16 & 1.7 & $4.9-6.1$ \\
\hline 2.92 & 0.14 & 1.5 & $5.2-6.5$ \\
\hline 2.74 & 0.12 & 1.32 & $5.5-6.9$ \\
\hline 2.52 & 0.20 & 1.10 & $6-7.6$ \\
\hline 2.23 & 0.16 & 0.81 & $7.1-8.9$ \\
\hline 2.01 & 0.14 & 0.59 & $7.7-9.6$ \\
\hline
\end{tabular}

sion at $2.74 \mathrm{eV})$. It should be noted that the calculations by formula (3.1) can only provide evaluation data, because they used the values of effective masses for bulk GaAs. In addition, first, the correlation between the number of light and heavy holes is unknown; second, the effective masses depend on the level of doping of crystallites [19, 20], third, the change in the stoichiometry of crystallites and chemical composition must also change the values of effective masses.

In order to verify the assumption about the origin of $\mathrm{PL}$ in GaAs samples due to the presence of nanoparticles, a small number of nanoparticles were removed from the GaAs surface and transferred to the solution. To do this, a small part of the sample (approximately $1 \mathrm{~cm}^{2}$ ) was immersed in $5 \mathrm{ml}$ of $96 \%$ ethyl alcohol containing $0.5 \mathrm{ml}$ of $10 \%$ ammonia solution and treated in an ultrasonic bath $(15 \mathrm{~W}, 40 \mathrm{kHz})$ for $40 \mathrm{~min}$. In the process of such treatment, due to ionization of hydroxyl groups on the surface of GaAs, two processes were envisaged: extraction of nanoparticles into the solution under the action of ultrasound and enhancement of surface oxidation. Both processes are caused by the appearance of a negative charge on the surface of both the porous structure of the matrix material and nanoparticles. The 
negative surface charge provides, on the one hand, the Coulomb repulsion of nanoparticles from the surface and facilitates their transfer into the solution and, on the other hand, facilitates the oxidation of GaAs.

Thus, after ultrasonic treatment of the sample, the PL spectra of both the obtained solution and the surface of the treated sample were recorded. The obtained spectra are presented in Fig. 7 (the spectrum of the original sample, the spectrum of the solution of nanoparticles in alcohol, and the spectrum of the sample after sonication in the solution).

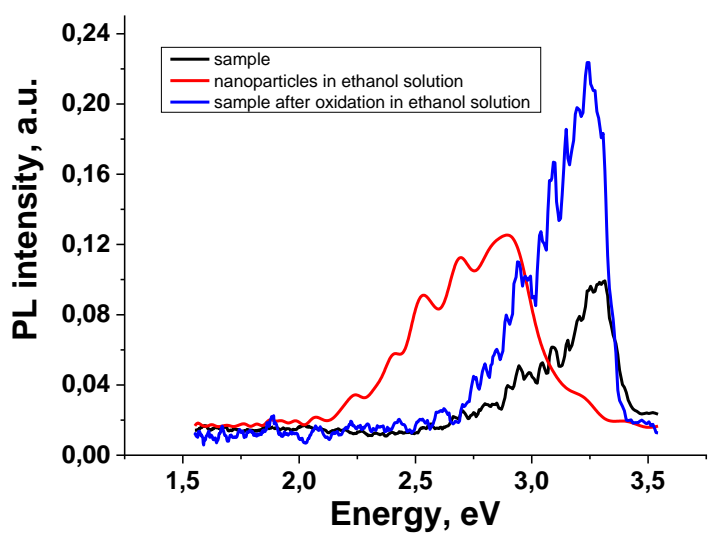

Fig. 7 - PL spectra with an excitation wavelength of $337 \mathrm{~nm}$ in the sample of porous GaAs, nanoparticles in ethanol solution, and in the sample after nanoparticles removal

As can be seen from Fig. 7, the PL of the colloidal solution with nanoparticles has a structured form with

\section{REFERENCES}

1. D.N. Goryachev, O.M. Sreseli, Semiconductors/Phys. Solid State 31 No 11, 1383 (1997).

2. M. Dmytruk, T. Barlas, V. Serdiuk, Phys. Chem. Solid State 11 No 1, 13 (2010).

3. T. Serdiuk, V. Lysenko, B. Mognetti, V. Skryshevsky, A. Géloën, J. Biophotonics 6 No 3, 291 (2013).

4. A. Saura, J. Monecke, G. Irmer, I.M. Tiginiyanu, G. Gartner, H.L. Hartnagel, J. Phys.: Condens. Mat. 13 No 31, 6687 (2001).

5. M. Naddaf, S. Saloum, Physica E 41 No 10, 1784 (2009).

6. A. Lebib, E. BenAmara, L. Beji, J. Lumin. 188, 337 (2017).

7. G. Flamand, J. Poortmans, phys. status solidi a 202 No 8, 1611 (2005)

8. T. Abdellaoui, J. Bennaceur, R. Chtourou, Physica E 43, 239 (2010).

9. J. Grym, D. Nohavica, P. Gladkov, E. Hulicius, J. Pangrac, K. Piksova, C.R. Chimie 16 No 1, 59 (2013).

10. A.N. Buzynin, Y.N. Buzynin, A.V. Belyaev, A.E. Luk'yanov, E.I. Rau, Thin Solid Films 515 No 10, 4445 (2007).

11. Y. Milovanov, V. Skryshevsky, I. Gavrilchenko, A. Oksanich, S. Pritchin, M. Kogdas, J. Electron. Mater. 48, 2587 (2019). maxima at $2.25,2.45,2.6,2.7$, and $2.9 \mathrm{eV}$, which is close to the values given in Table 1 and Table 2 for the porous GaAs layer. After oxidation of the sample surface, the PL spectrum is similar to Fig. 4.

\section{CONCLUSIONS}

The research of the structural and morphological properties of porous GaAs layers obtained by electrochemical etching method is carried out in the work.

The analysis of SEM images of the surface and the chipping of these structures showed the presence of a porous layer with a depth of about $21 \mu \mathrm{m}$, which consisted of non-uniformly distributed on the surface mesoand macropores and nanocrystallites. Pyramidal formations $\sim 30 \mu \mathrm{m}$ in height were found on some structures. Measurements of Auger spectra showed different stoichiometry of GaAs on the porous and crystalline parts of the samples. This means a change in the chemical composition of nanocrystallites compared to the original plate, i.e., $\mathrm{Ga}$ is etched $20 \%$ more than As.

Based on the study of the PL spectra of porous GaAs and their comparison with the spectra of hydrated oxides of $\mathrm{Ga}$ and As, an assumption was made about the nature of the PL. Thus, there is a contribution of the spectra of $\mathrm{As}_{2} \mathrm{O}_{3} \cdot n \mathrm{H}_{2} \mathrm{O}$ and $\mathrm{Ga}_{2} \mathrm{O}_{3} \cdot n \mathrm{H}_{2} \mathrm{O}$ hydrated oxides formed on the surface of our structure, but, on the other hand, there is a contribution of other PL mechanisms, in particular, quantum-dimensional effects. The possible sizes of nanocrystallites were estimated from the PL spectra, and in electrochemically etched GaAs they vary from about 4.8 to $11.4 \mathrm{~nm}$.

12. Yu.N. Buzynin, S.A. Gusev, V.M. Danil'tsev, M.N. Drozdov, Yu.N. Drozdov, A.V. Murel, O.I. Khrykin, V.I. Shashkin, Tech. Phys. Lett. 26, 298 (2000).

13. M. Naddaf, M. Saad, Vacuum 122, 36 (2015).

14. H. Foll, S. Langa, J. Carstenen, I.M. Tiginyanu, Adv. Mater. 15 N 3, 183 (2003).

15. C. Delerue, M. Lannoo, Nanostructures: Theory and Modeling (Springer-Verlag: Berlin Heidelberg GmbH: 2004).

16. T. Serdiuk, V.A. Skryshevsky, I.I. Ivanov, V.V. Lysenko, Mater Lett. 65 No 15, 2514 (2011).

17. M.A. Malik, P. O'Brien, S. Norager, J. Smith, J. Mater. Chem. 13, 2591 (2003).

18. T. Salminen, J. Dahl, M. Tuominen, P. Laukkanen, E. Arola, T. Niemi, Opt. Mater. Express. 2 No 6, 799 (2012).

19. K. Watanabe, S. Tsukamoto, Y. Gotoh, N. Koguchia, J. Cryst. Growth 227-228, 1073 (2001).

20. T. Hatke, M.A. Zudov, J.D. Watson, M.J. Manfra, L.N. Pfeiffer, K.W. West, Phys. Rev. B 87, 161307(R) (2013). 


\section{Люмінесцентні властивості електрохімічно травленого арсеніду галію}

І.В. Гаврильченко ${ }^{1}$, Ю.С. Мілованов ${ }^{1}$, І.І. Іванов ${ }^{1}$, О.Н. Задерко ${ }^{1}$, А.П. Оксанич ${ }^{2}$, С.Е. Притчин ${ }^{2}$ М.Г. Когдась 2 , М.I. Федорченко ${ }^{3}$, С.М. Гойса ${ }^{3}$, В.А. Скришевський ${ }^{1}$

${ }^{1}$ Інститут високих технологій, Київський національний університет ілені Тараса Шевченка, вул. Володимирська 64, 01601 Київ, Україна

${ }_{2}^{2}$ Креленчуцький національний університет ілені Михайла Остроградського, вул. Першотравнева 20 , 39600 Креленчук, Україна

3 Факультет радіоббізики, електроніки та колп'ютерних систел, Київський національний університет ілені Тараса Шевченка, вул. Володимирська 64, 01601 Київ, Украӥна

У роботі наведено результати структурних і фотолюмінесцентних (ФЛ) досліджень пористих шарів GaAs, що створюються шляхом електрохімічного травлення пластин GaAs. Структурні та морфологічні властивості пористого GaAs проаналізовані методом CEM та за допомогою Оже-спектроскопії. При аналізі СЕМ зображень було показано наявність пористого шару глибиною близько 21 мкм, що складався з нерівномірно розподілених по поверхні мезо- та макропор і нанокристалітів. На деяких структурах було виявлено пірамідальні утворення висотою 30 мкм. Виміри Оже-спектрів показали різну стехіометрію GaAs на пористих та кристалічних частинах зразків. Фотолюмінесценція утвореного матеріалу характеризувалася смугою випромінювання в області 1,5-3,2 еВ, причому спостерігалась залежність спектру ФЛ від довжини хвилі збуджуючого світла. Із збільшенням довжини хвилі збуджуючого світла максимуми спектрів випромінювання зміщуються в область менших енергій. Така поведінка спектру ФЛ (зсув максимуму ФЛ в залежності від довжини хвилі збуджуючого випромінювання) характерна для гетерогенних по товщині електрохімічно травлених пористих структур. Обговорюється природа багатосмугового спектру ФЛ пористого GaAs за рахунок існування гідратованих оксидів арсену та галію на поверхні зразків та утворення нанокристалітів у пористих шарах GaAs. B cтатті представлена оцінка можливих розмірів нанокристалітів у припущенні, що ФЛ створюеться за рахунок квантово-розмірних ефектів.

Ключові слова: Фотолюмінесценція, Пористий GaAs, Нанокристаліти, Оже-спектроскопія. 